\title{
AD REGEM: USOS DAS RETÓRICAS EPIDÍTICA E JUDICIAL NA DEDICATÓRIA DA CRÔNICA DA GUINÉ (SÉCULO XV)
}

\author{
AD REGEM: USES OF EPIDEICTIC AND FORENSIC \\ RHETORICS IN THE CHRONICLE OF GUINEA'S \\ DEDICATORY (FIFTEENTH CENTURY)
}

Jerry Santos Guimarães* Marcello Moreira**

\begin{abstract}
Resumo: Temos por objetivo demonstrar como Gomes Eanes de Zurara, segundo cronista-mor da Dinastia de Avis no século XV lusitano, fez uso de procedimentos retóricos numa obra historiográfica, qual seja, a Crônica da Guiné, mais especificamente na sua dedicatória ao Infante D. Henrique.
\end{abstract}

Palavras-chave: Retórica. História. Crônica da Guiné.

Abstract: We have as pourpose to demonstrate how Gomes Eanes de Zurara, second chief chronicler of the House of Avis in the fifteenth century Lusitanian, made use of rhetorical procedures in a work of historiography, namely, the Chronicle of Guinea, more specifically in its dedication to Prince D. Henrique.

Keywords: Rhetoric. History. Chronicle of Guinea.

\footnotetext{
* Professor de História no Ensino Médio da rede pública de ensino do Estado da Bahia. E-mail: jerryguima@gmail.com

** Professor titular de Literatura Brasileira no Departamento de Estudos Linguísticos e Literários (DELL) da Universidade Estadual do Sudoeste da Bahia (UESB).

E-mail: moreira.marcello@gmail.com
} 


\section{INTRODUÇÃO: UMA HISTÓRIA RETORICAMENTE REGRADA}

A retórica é definida por Aristóteles em sua obra homônima como uma arte (do grego téchne), ou seja, um conjunto de princípios gerais e de regras definidas que podem ser compreendidos pela razão e cujo fim último é a persuasão. ${ }^{1}$ Todo ser humano, porque vive em sociedade e porque muitas vezes quer convencer outra pessoa a respeito de algo, usa, de uma forma ou de outra, de algum artifício retórico. Mas só o estudo de tal arte e de seus procedimentos técnicos poderia aumentar sobremaneira a capacidade persuasiva de alguém, de acordo com o Estagirita. E tal concepção perdurou na Idade Média europeia, uma vez que o correspondente latino de téchne, ars, nada mais é, segundo Curtius, que "um conhecimento reduzido a regras". ${ }^{2}$

Três são os gêneros da retórica, segundo Aristóteles: o deliberativo, o judicial e o epidítico. ${ }^{3} \mathrm{O}$ gênero deliberativo, próprio dos políticos, diz respeito ao futuro, e busca convencer aos ouvintes sobre a conveniência de se tomar determinada decisão. Já o gênero judicial volta-se para o passado e, como o próprio nome indica, é utilizado principalmente por advogados que querem convencer ao juiz e ao júri se um crime foi cometido ou não, e, em caso afirmativo, se a pena deve ser mais branda ou severa. Por fim, o gênero epidítico, também chamado demonstrativo, tem como tempo o presente, e objetiva louvar ou censurar alguém, segundo sua dignidade.

O gênero epidítico é próprio de poetas e historiadores. Mas o que diferencia a poesia da história? Na sua Poética, Aristóteles nos diz que não é tanto a forma como elas são escritas, e sim o conteúdo do que é escrito. Enquanto a história dedica-se a dizer "as coisas que sucederam", a poesia trata das coisas "que poderiam suceder". ${ }^{4}$ Segundo a antiga retórica latina, tributária e emuladora da retórica grega, a história faz parte de um gênero da narrativa que se centra especialmente nas ações, ou nos feitos. Enquanto a fábula ocupa-se de "ações que não são nem verdadeiras nem verossímeis", e o argumento do que não aconteceu, "mas poderia ter acontecido", a história "são as ações realmente empreendidas", segundo nos diz o anônimo autor da Retórica a Herênio. ${ }^{5} \mathrm{Ou}$, conforme Cícero afirma no De Oratore: "Pois, quem desconhece ser a primeira lei da história não ousar não dizer algo de falso? Em seguida, que não se ouse não dizer algo de verdadeiro?". ${ }^{6}$

Assim, quando Aristóteles escreve em sua Retórica que o gênero epidítico é próprio de poetas e historiadores, ele tem em mente que o discurso destes últimos, diferentemente do dos primeiros, trata de acontecimentos verídicos. Mas não basta que o discurso histórico seja verdadeiro; ele deve também parecer verdadeiro, ou seja, deve ser verossímil. É por isso que se requeria da história, além da verdade, a verossimilhança. $\mathrm{O}$ uso da arte retórica 
deveria trabalhar neste sentido, qual seja, produzir nos leitores o efeito de verossimilhança a respeito do que é narrado. Segundo Cícero:

Plausível será a narração que pareça conter todas as características habituais da verdade: que dê conta da dignidade das pessoas; que destaque as causas dos acontecimentos; se poderiam ter sido realizados por alguém; se mostra que o tempo foi adequado, o espaço suficiente, o lugar apropriado para o ato em pauta; devendo este ser apresentado de maneira conveniente ao caráter das partes, à opinião pública e aos sentimentos do auditório.?

Deste modo, ao louvar o príncipe como exemplo a ser seguido, tanto o historiador da Antiguidade Clássica quanto o cronista da Idade Média deveriam buscar atender a dois critérios: o da verdade e o da verossimilhança. O mundo medieval havia conservado a divisão tripartite de Aristóteles, exposta em sua Poética: haveria sempre "homens melhores, piores ou iguais a nós". ${ }^{8}$ Ora, situando-se o príncipe evidentemente na categoria dos "melhores do que somos", o seu elogio por parte do cronista deveria estar de acordo com o que se esperava de alguém de tal envergadura - daí muitas vezes a sobreposição da verossimilhança sobre a verdade nas crônicas medievais. O mesmo acontecia em tais narrativas quando censuravam os homens "piores do que somos": a verossimilhança, ou "a ordem natural das coisas", no dizer de Guenée, criava uma expectativa a priori que levava o cronista, no intuito de atendê-la, a não se apegar tão ferrenhamente à verdade. ${ }^{9}$

A problemática da verossimilhança nas crônicas medievais era uma questão ambígua, segundo Guenée. Por mais que a intenção manifesta do historiador fosse a escrita da verdade do que aconteceu, a aparência de verdade prevalecia. O verossímil e o autêntico, ou seja, o que era atestado por alguma autoridade, e não necessariamente o verdadeiro, eram, no final das contas, os critérios do historiador medieval:

Os historiadores eram muito estimulados a ir nessa direção, porque se proclamavam sua vontade de dizer o que realmente tinha acontecido, frequentemente também pensavam que sendo seu dever fornecer os melhores exemplos, era melhor relatar o que deveria ter acontecido. ${ }^{10}$

Na construção da sua narrativa histórica, portanto, o cronista medieval utilizava artifícios retóricos primeiramente devido ao seu desejo de persuadir aos seus leitores e ouvintes sobre a verdade do que aconteceu. E quando apontava como memoráveis os exemplos que deveriam ser imitados ou 
repudiados, o cronista fazia uso da matéria própria da retórica epidítica: o louvor e a censura. É por isso que os cronistas do século XV, dependentes dos seus príncipes patrocinadores, muitas vezes confundem-se com panegeristas, como nos informam Bourdé e Martin. ${ }^{11}$ Assim, segundo Ricoeur, não é apenas a coerção física que é utilizada pelos detentores do poder na manipulação da memória e do esquecimento na construção de sua identidade: "Até o tirano precisa de um retórico, de um sofista, para transformar em discurso sua empreitada de sedução e de intimidação". ${ }^{12}$

É importante lembrar que os gêneros retóricos não são fechados em si mesmos, e um único discurso pode comportar variados graus de cada um deles. Como ressaltado por Maleval, dificilmente há o uso exclusivo de um gênero retórico; o que mais se observa é a predominância de um sobre os outros: "E se na Antiguidade Clássica tal fato já se podia constatar, muito mais na Idade Média se acentuaria o imbricamento de gêneros". ${ }^{13}$ De fato, segundo Curtius, desde o fim da Idade Antiga já era observável uma "confusão e mistura dos diversos estilos". ${ }^{14}$ Assim, se o gênero típico dos historiadores é o epidítico, segundo Aristóteles, nada impediria que o cronista medieval utilizasse a refutatio, própria do gênero judicial, para defender seu príncipe de alguma acusação. Além do mais, uma crônica poderia ser escrita também com o objetivo de convencer a alguém a tomar uma decisão de caráter político no futuro, como é adequado à retórica deliberativa. Isto aconteceu, aliás, no caso da própria Crônica da Guiné, escrita a mando do rei D. Afonso V (1432-1481) para conseguir uma bula papal que ampliasse os direitos lusitanos sobre as terras africanas, conforme veremos adiante. Poderia ser o caso ainda de o cronista ter de reconstituir um discurso deliberativo, como acontece na Crônica da Tomada de Ceuta, onde Zurara põe na boca do Fr. João Xira palavras que visavam a convencer os soldados portugueses, a maioria de origem campesina, a lutarem bravamente, até a morte se fosse necessário, contra os mouros africanos. ${ }^{15}$

A retórica não deveria ser desprezada por quem se dedica a estudar as ideias europeias durante a Idade Média, uma vez que, segundo Curtius, ela nos introduz em profundidade no mundo medieval. ${ }^{16} \mathrm{~A}$ instituição retórica, aliás, nascida no mundo greco-romano, atravessou toda a Idade Média e vigorou até meados do século XVIII, de acordo com Hansen. ${ }^{17}$ As tópicas retóricas eram, assim, um verdadeiro "celeiro de provisões" ao qual recorriam tanto poetas quanto historiadores. ${ }^{18} \mathrm{Com}$ os seus topoi, argumentos direcionados tanto à razão quanto ao coração e aplicáveis nos mais diferentes casos, a retórica penetrou em variados gêneros literários. Nem todos os topoi, no entanto, são oriundos da antiga arte retórica, sendo observáveis no decorrer da Idade Média tanto o surgimento de novas tópicas quanto a permuta de tópicas entre a prosa e a poesia. O conhecimento dos topoi não adviria somente dos tratados de retórica, mas poderia ser introjetado e reproduzido a partir de textos dos mais 
diversos gêneros, e que também faziam uso dos lugares-comuns postos em circulação pela instituição retórica. Instituição esta que não se limitava aos manuais de retórica. Assim, a história tanto criou suas próprias tópicas quanto recebeu da poesia e de outros textos de prosa diversas preceptivas. Para que um discurso historiográfico medieval fosse minimamente compreendido, portanto, orador - ou autor - e público receptor deveriam compartilhar de uma mesma "memória dos topoi". ${ }^{19}$ Cabia ao produtor do discurso selecionar os lugarescomuns conhecidos e adequados à sua matéria e, a partir de sua capacidade inventiva, tentar persuadir seus leitores e ouvintes, que poderiam então julgar seu desempenho.

\section{RETÓRICA E HISTÓRIA NO SÉCULO XV PORTUGUÊS}

Os Quatrocentos lusitanos foram um período especialmente fértil tanto para a produção retórica quanto para a prática da escrita da história. Embora ambas já fossem cultivadas em Portugal em tempos anteriores, especialmente nos mosteiros de Santa Maria de Alcobaça e de Santa Cruz de Coimbra, foi somente a partir do século XV que elas foram institucionalizadas pela Coroa. A partir de então a Casa de Avis se apropriou da retórica e da história enquanto meios oficiais de legitimação.

O ensino das Artes na Universidade de Lisboa, fundada provavelmente em 1289 por D. Dinis, funcionou durante muito tempo incompleto, oferecendo apenas os estudos de gramática e de dialética (ou lógica). A retórica, bem como a aritmética, a música, a geometria e a astronomia só foram incluídas no século $\mathrm{XV}{ }^{20}$ Vários príncipes avisinos sentiram a necessidade do ensino da retórica em seu país. O Infante D. Henrique (1394-1460), que à maneira de outros membros da família real foi protetor e governador da Universidade, deixou em testamento uma verba específica para a cadeira de retórica. ${ }^{21} \mathrm{O}$ Infante D. Pedro (1392-1449) traduziu o De Officiis, de Cícero, e conhecia o Liber Declamationum de Sêneca, o Retor. O rei D. Duarte (1391-1438) encomendou a tradução para o vernáculo do De Inuentione, de Cícero. ${ }^{22}$ Seu filho e sucessor, o rei $\mathrm{D}$. Afonso $\mathrm{V}$, escreveu de próprio punho uma carta ao seu cronista, Gomes Eanes de Zurara, onde lhe diz o seguinte:

[...] muitos sam os que se daõ ao exercício das armas e mui poucos ao estudo da arte oratória : assi que pois vos sois nesta arte assaz ensinado e a natureza vos deu mui gram parte delia: com muita rrazão eu e os prinçipes de meus rreinos e capitães deuem dauer a merçe que vos seja feita por bem empreguada. ${ }^{23}$ 
Com respeito à escrita da história, antes dos Quatrocentos já eram produzidos em Portugal hagiografias, memórias de fundação de mosteiros, anais, livros de linhagens e crônicas. ${ }^{24}$ Mas a "produção historiográfica de iniciativa régia" só começou mesmo com a Crônica de 1419, de provável autoria de Fernão Lopes (c. 1379-1459) e encomendada por D. Duarte quando ainda era infante. ${ }^{25}$ Já rei, D. Duarte, no seu Livro da Ensinança de Bem Cavalgar Toda Sela, recomendou a senhores e cavaleiros a leitura de crônicas por conta dos "grandes e boos exempros e sabedorias que muyto prestam (...) aos tempos da necessydade". ${ }^{26} \mathrm{E}$ também o rei $\mathrm{D}$. Afonso V ressaltou, na mesma carta acima referida, a importância do trabalho do cronista Zurara como ordenador da história oficial do reino na Crônica da Tomada de Ceuta:

[...] ajnda que os feitos de Cepta sejam assaz de rrezentes: depois que eu vi a coronica que vos delles escreuestes a muitos fiz homrra e mercê com melhor vontade por ser certo de alguús boõs feitos que laa fizerão por seruiço de Deos e dos rreis meus antecessores e meu: e a outros por serem filhos daquelles que assi laa bem seruiram: do que eu nam era amtes em tam comprido conhecimento: e creo que nom menos seraa aos que depois de mim vierem, quando virem ho que aveis de escrever dos feitos de Alcácer, e se alguũs merecem gloria por jrem a essa terra por seruirem a Deos e a mim e fazerem de suas homrras : vos assaz sois de louuar que com desejo descreuer ha verdade do que elles fizeram $[\ldots]{ }^{27}$

A historiografia medieval era, segundo Guenée, "instrumento de memória". ${ }^{28}$ Mas memória de quê? "Só devia fixar o que era digno de lembranças e relatar coisas memoráveis. Isto é, os prodígios, as guerras, os atos de príncipes e santos. ${ }^{29}$ Deste modo, a memória que o cronista da Idade Média estava incumbido de salvar do esquecimento era uma memória que, se por um lado ainda preservava seu aspecto hagiográfico, por outro passou a se interessar mormente pelos príncipes e por seu feitos notáveis - o que incluía também as grandes ações de seus vassalos importantes. Uma vez que a corte tornou-se, durante a Baixa Idade Média, o centro de produção historiográfica por excelência, nada mais natural, portanto, que os feitos de reis e nobres fossem exaltados a partir de então. ${ }^{30}$

As narrativas históricas, ao mesmo tempo em que louvavam as gesta dos príncipes e de sua corte, usavam-nos como exemplos a serem seguidos tanto pelo público receptor imediato das crônicas quanto pelas novas gerações que se sucederiam. Isto não era exatamente uma prática nova, já que há muito os clérigos vinham usando exemplos bíblicos em seus sermões moralizantes. 
Mas agora, além de a escrita da história ser levada a cabo também por leigos, exemplos extraídos das narrativas históricas, e não apenas das hagiografias ou da Bíblia, passaram a ser utilizados. ${ }^{31}$

Vigorou durante muito tempo na tradição historiográfica europeia, de acordo com Koselleck, o topos historia magistra vitae, ou "a história é mestra da vida", segundo o qual os leitores da história poderiam tirar proveito dela na medida em que aprendessem quais exemplos deveriam ser imitados ou não. ${ }^{32}$ A história teria uma função pragmática: ajudar os homens do presente a agir segundo as palavras e os atos dos homens do passado, evitando seus erros e repetindo seus acertos. E outro não era o objetivo da escrita da história entre os antigos gregos e latinos, e mesmo entre os homens da Idade Média.

Mas quem tem o poder de decidir que feitos são dignos de ser lembrados ou esquecidos? Em Portugal, no século XV, ninguém menos que o rei. A própria escolha de Zurara como cronista, em 1450, e sua posterior nomeação como cronista-mor do reino, quatro anos depois, fez parte de uma sistemática operação engendrada por D. Afonso V para apagar a boa memória que se tivesse de seu tio, D. Pedro, especialmente no que se refere ao período de sua regência. ${ }^{33}$ Manipulando de tal forma a memória coletiva e tencionando provocar uma amnésia coletiva, o rei e sua dinastia agiam como senhores da memória e do esquecimento, segundo Le Goff. ${ }^{34}$

O ofício de cronista-mor tinha uma peculiaridade em Portugal, pois além de ser responsável por ordenar a história oficial da dinastia real e de alguns de seus vassalos importantes, o cronista-mor era também guarda-mor dos arquivos régios. ${ }^{35}$ É por isso que, segundo França, as crônicas de então

[...] eram escritas para servir como certidão verdadeira do passado do reino. Nesse sentido, tinham, entre outras funções, uma função que as aproximava das escrituras oficiais guardadas no Tombo e em outros arquivos: não permitir que as experiências passadas fossem apagadas sem que ficasse um legado para a posteridade. ${ }^{36}$

A relação entre o príncipe e seu cronista era de simbiose, especialmente na Europa do século XV. ${ }^{37}$ Se por um lado Zurara ascendia socialmente, "gozando as rendas fáceis de uma comenda de Cristo" ${ }_{38}$ à medida que substituía Fernão Lopes como cronista oficial da Coroa Portuguesa, por outro o Infante D. Henrique e o seu sobrinho, o rei D. Afonso V, careciam de um escritor apto a elogiá-los e legitimá-los após o desastroso cerco a Tânger ${ }^{39}$ e a Batalha de Alfarrobeira ${ }^{40}$, respectivamente. Deste modo, podemos afirmar que também os príncipes achavam-se como que dependentes de seus cronistas, já que não 
podiam "passar sem os seus serviços historiográficos, que têm a missão de os exaltar e de defender a sua razão". ${ }^{41}$

Não vemos de forma gratuita, como uma coincidência apenas, o patrocínio e o incentivo dos estudos de retórica pela Dinastia de Avis no mesmo período em que ela oficializava a escrita da história. Ressaltamos que retórica e história eram estudadas simultaneamente nos mosteiros, antes de serem assumidas pela Coroa. Parece-nos claro, portanto, que o estudo de uma estava atrelado ao da outra. O projeto de memória e de esquecimento dos reis avisinos necessitava tanto da história, gênero literário que se distinguia pela escrita da verdade, quanto da verossimilhança, alcançável por meios retóricos.

\section{A CRÔNICA DA GUINÉ}

A Crônica da Guiné foi escrita especialmente para a obtenção de uma bula papal que ampliasse os direitos portugueses sobre o "Mar Oceano". Ao narrar as descobertas portuguesas que entre 1434 e 1448 já haviam ultrapassado o Cabo Bojador e chegado à Guiné, ${ }^{42} \mathrm{D}$. Afonso $\mathrm{V}$ requeria do papa Nicolau V (1397-1455) o reconhecimento do que os portugueses já haviam encontrado na costa africana. A Crônica da Guiné foi concluída oficialmente em fevereiro de 1453. A bula Romanus Pontifex veio em janeiro de 1455, e concedia a Portugal a posse de todas as terras descobertas ou por descobrir ao sul do Cabo Bojador. ${ }^{43}$

Não podemos, portanto, perder de vista nem as relações intrínsecas entre retórica e história no Portugal do século XV, nem as motivações políticas que levaram o rei D. Afonso V a confiar a Gomes Eanes de Zurara a ordenação oficial da história da descoberta e dos feitos portugueses na Guiné. Conforme veremos a seguir, tais características transparecem na dedicatória de tal crônica ao Infante D. Henrique.

\section{A DEDICATÓRIA DA CRÔNICA DA GUINÉ E A RETÓRICA EPIDÍTICA}

A dedicatória da Crônica da Guiné ao Infante D. Henrique principia com as seguintes palavras: "Ó tu, Principe pouco menos que divinal!". ${ }^{44}$ Tal panegírico, registrado nos capítulos II a VII da Crônica, segue bem de perto os preceitos estabelecidos pela Retórica a Herênio. ${ }^{45} \mathrm{O}$ gênero retórico demonstrativo (ou epidítico), utilizado para o elogio ou o vitupério, é tratado especificamente no seu Livro III, parágrafos 10-15. Segundo o desconhecido autor, o elogio deve ser construído a partir das coisas externas, do corpo e do ânimo: 
Coisas externas são aquelas que podem acontecer por obra do acaso ou da fortuna, favorável ou adversa: ascendência, educação, riqueza, poder, glória, cidadania, amizades, enfim, coisas dessa ordem e seus contrários. Ao corpo pertence o que a natureza lhe atribuiu de vantajoso ou desvantajoso: rapidez, força, beleza, saúde e seus contrários. Dizem respeito ao ânimo as coisas que comportam nossa deliberação e reflexão: prudência, justiça, coragem, modéstia e seus contrários. ${ }^{46}$

Esta é, pois, a "tríplice divisão do elogio e do vitupério". ${ }^{47} \mathrm{O}$ esquema a seguir no caso específico do discurso laudatório é o seguinte: 1. Introdução, que apresenta quem vai ser elogiado; 2. Narração dos feitos dignos de louvor (opcional); 3. Das circunstâncias externas, especificamente a ascendência de quem se fala; 4. Das vantagens do corpo; 5. Virtudes do ânimo, observadas a partir da relação do elogiado com as circunstâncias externas; 6. Conclusão. Tal esquema é fielmente seguido por Zurara na construção da bela persona do Infante D. Henrique.

No capítulo II da Crônica da Guiné ("Invocação do autor") encontramos a introdução do elogio, seguida de uma breve narração dos "altos feitos" de D. Henrique. Dentre as quatro possibilidades oferecidas pela Retórica a Herênio, Zurara opta por tirar a introdução "da pessoa de quem falamos", o que é mais apropriado à dedicatória em questão. A regra a seguir neste caso é dizer "que tememos não poder igualar seus feitos com palavras, que todos os homens devem proclamar tais virtudes, que os fatos em si superam a eloquência de todos os apologistas". ${ }^{48}$

Zurara roga às "sagradas virtudes" do Infante para que "suportem com toda paciencia o falecimento de [sua] ousada pena, querendo tentar uma tão alta materia como é a declaração" das virtuosas obras de D. Henrique. ${ }^{49}$ Percebemos aqui o uso do cleuasmo, "figura pela qual o orador finge depreciar-se para se fazer mais apreciar", angariando assim a confiança e a simpatia do auditório. ${ }^{50}$ $\mathrm{E}$, além disso, a amplificação das virtudes do Infante. O cronista cumpre assim a primeira parte do preceito a ser observado na introdução do elogio ("tememos não poder igualar seus feitos com palavras").

A glória, os louvores e a fama do príncipe são tais que, segundo Zurara, desde as "almas inocentes daquelas barbaras nações", ou seja, os infiéis mouros azenegues e os gentios negros da Guiné, até os cristãos alemães, franceses, ingleses e italianos, "acompanhados doutros de diversas nações e linguagens, toda gente estremada em linhagem e vertude", ${ }^{11}$ devem louvar seu engenho e sua liberalidade, o que confirma a segunda parte do preceito da introdução da dedicatória, conforme prescrito pela Retórica a Herênio ("que todos os homens devem proclamar tais virtudes"). 
Zurara põe-se então a narrar os feitos louváveis do príncipe. Graças às suas obras, escreve o cronista, bárbaros puderam viajar a Portugal e conhecer a salvação de suas almas através da conversão e desfrutar das maravilhas da civilização cristã, salvando de tal modo também a seus corpos do anterior viver bestial. Que dizer do povo lusitano? Senhores, prelados, fidalgos, viúvas, cavaleiros, religiosos, "graduados em todalas ciências", escolares, escudeiros, oficiais mecânicos, enfim, da nobreza à arraia miúda, gentes de todas as ordens foram agraciadas com a liberalidade de D. Henrique:

Uns me mostravam vilas e castelos; outros lugares e terras chãs; outros comendas de grossas rendas; outros grandes e abastados reguengos; outros quintãs e herdades e foros, outros, cartas de tenças e de casamentos; outros, ouro e prata e dinheiros, e panos; outros, saude nos corpos e escapamento de perigos, que pelo teu azo cobraram; outros, servos e servas infindos, outros me contam de moesteiros e igrejas, que repairaste e fizeste de novo, com grandes e ricos ornamentos que ofereceras em muitos lugares piedosos; outros me mostravam os sinais dos ferros que traziam no cativeiro de que os tiraste. ${ }^{52}$

A narração prossegue com muitos outros feitos do Infante de modo a que os leitores cheguem à conclusão de que "os fatos em si superam a eloqüência de todos os apologistas", em conformidade com a parte final do preceito relativo à introdução do elogio. Até mesmo os mouros escravizados "pela guerra mui cruel" do príncipe no Marrocos vêm, segundo Zurara, agradecer ao Infante por tê-los libertado da "cegueira em que estavam" por seguirem "Mafamede"! 53

No capítulo III da Crônica ("Em que conta a geração de que descende o Infante D. Henrique"), atende-se à primeira parte da "tríplice divisão do elogio" segundo a Retórica a Herênio: a ascendência, uma das circunstâncias externas do elogiado. O preceito estabelecido para alguém de nobre ascendência é que a persona seja "semelhante ou superior" aos seus antepassados. ${ }^{54}$ Cumprindo o princípio da brevidade na narrativa, ${ }^{55}$ Zurara apresenta-nos a parentela mais próxima de D. Henrique. O interessante é a maneira como o faz: o príncipe, além de ser filho de rei (D. João I), é também sobrinho de rei (Henrique IV da Inglaterra, irmão de sua mãe, D. Filipa de Lencastre), irmão de rei (D. Duarte) e tio de rei (D. Afonso V). Deste modo, Zurara pretende realçar a magnificência de D. Henrique, que, se é "príncipe sem coroa", ${ }^{56}$ compartilha da realeza dos de sua casa, em cujas veias corre "o mais nobre e mais alto sangue da cristandade". ${ }^{57}$ Zurara nada fala sobre a ascendência de D. João I, pai de D. Henrique, pois se o fizesse teríamos um príncipe, nas palavras do historiador português Oliveira Martins, "filho de um bastardo que nascera em entranhas 
populares", o que poderia soar por demais vituperante..$^{58}$ Melhor então atender, conforme destacado acima, ao preceito da brevidade e não voltar muito no tempo - duas gerações apenas! - a ascendência do Infante.

O capítulo seguinte ("Que fala dos costumes do Infante D. Henrique") efetiva a segunda parte da "tríplice divisão do elogio": as vantagens do corpo. Para ser elogiada, a persona deve ter, segundo a Retórica a Herênio, "beleza e proporção naturais", "força e velocidade excelentes", "boa saúde" adquirida através do "cuidado de si" e da "moderação dos desejos". ${ }^{59}$ Zurara é da opinião de que as boas feições corporais não são garantia de virtude. Mas como não quer deixar de atender a nenhuma preceptiva retórica em sua dedicatória, o cronista nos pinta a seguinte imagem corpórea do Infante: "estatura do corpo em boa grandeza, e foi homem de carnadura grossa e de largos e fortes membros; a cabeladura havia algum tanto alevantada; a cor de natureza branca, mas pela continuação do trabalho por tempo tornou doutra forma" ${ }^{60}$ Cultor da temperança, o D. Henrique elogiado por Zurara repudiou de tal maneira a luxúria "que virgem o recebeu a terra" ${ }^{61}$ Seus olhos não se fechavam enquanto houvesse trabalho por fazer. ${ }^{62}$ De compleição freima, sabia o Infante moderála ao ser "em algumas cousas vagaroso". ${ }^{63}$ Abstinha-se ainda do vinho. ${ }^{64}$ Não usava sua boca para falar palavras torpes ou desonestas. ${ }^{65}$

Lembremo-nos, porém, de que estamos diante de um discurso do gênero demonstrativo, ou epidítico. Conforme Reboul destacou, a argumentação típica de tal gênero retórico se dá principalmente pelo uso de amplificações, recurso que consiste em ressaltar a importância do que se diz. ${ }^{66}$ Isto significa, pois, que não devemos aceitar como "verdade histórica" tudo o que o cronista diz de seu príncipe. Em tal erro incorreu Oliveira Martins, que tomou como literal a morte casta de D. Henrique, apregoada por Zurara ${ }^{67}$ Ora, foi encontrada na Biblioteca Vaticana uma petição onde o Infante D. Henrique solicita ao papa permissão para conceder uma das comendas da Ordem de Cristo a uma filha natural sua. ${ }^{68}$ Sabemos que, segundo a moral cristã - nem sempre seguida pela Dinastia de Avis, cujo exemplo clássico é o seu próprio fundador, D. João I, ele mesmo bastardo e pai de filho ilegítimo, o Conde de Barcelos - quem não houvesse contraído laços matrimoniais deveria permanecer casto. Tal princípio da castidade presumida do cristão solteiro - caso de D. Henrique - é que foi amplificado por Zurara.

É ainda no capítulo IV que o cronista passa a cumprir a terceira parte do elogio, ou seja, o modo como o ânimo do elogiado lidou com as circunstâncias externas para a produção e a manifestação de suas virtudes. Vejamos o que nos diz a Retórica a Herênio a esse respeito:

Foi rico ou pobre? Com que poder, que glória, que amizades e inimizades? O que fez corajosamente para gerar 
inimizades? Com que fé, benevolência e dever conduziu suas amizades? Que tipo de homem foi na riqueza e na pobreza? Com que tipo de ânimo exerceu o poder? ${ }^{69}$

De acordo com o cronista, o Infante D. Henrique caracterizava-se principalmente pela sua liberalidade, e sua fama era tal que acorriam à sua casa desde os fidalgos do reino até os estrangeiros, cujo bom acolhimento implicava "acrecentar muito em suas despesas". ${ }^{70}$ Daí depreende-se que, sendo rico, soube utilizar seus bens materiais em favor de amigos e desconhecidos. Aos inimigos, reafirma Zurara, o príncipe destinava sua cruel mas justa virtude guerreira ao derrotá-los e trazê-los à santa fé católica e, portanto, à salvação de suas almas, segundo se cria.

Mas há algo de censurável no Infante D. Henrique: "reprochavam os entendidos que falecia na justiça distributiva". ${ }^{71}$ Repare-se que não é o autor do discurso laudatório quem imputa esta falta ao príncipe. Este é o juízo de outros homens. Conforme tais "entendidos" não nomeados por Zurara, isto ocorreu quando D. Henrique, após a infausta campanha contra a cidade marroquina de Tânger, em 1437, recompensou mais aos que o abandonaram do que aos que lhe foram fiéis no campo de batalha. Zurara vê nisto, retoricamente, as virtudes do príncipe de não guardar ódio ou rancor. Se há algo de censurável no Infante, só o é em decorrência das suas virtudes, e não dos vícios! E à virtude só se pode dispensar elogios, e não censuras.

Como poderia Zurara incluir tal censura em seu discurso laudatório? Entre os preceitos da narração trazidos pela Retórica a Herênio está a verossimilhança: "Devemos forjar com cautela coisas que envolvem documentos escritos ou a autoridade incontestável de alguém". ${ }^{72}$ A derrota portuguesa em Tânger tinha acontecido há relativamente pouco tempo. Testemunhas do ocorrido havia que podiam muito bem acusar D. Henrique de ter cometido aquela falta. Ainda que não correspondesse necessariamente à verdade, o elogio do príncipe deveria ser verossímil, e não poderia desconsiderar tal fato. É por isto que Zurara promete voltar a esta espinhosa questão no sexto capítulo da Crônica, e pretende resolvê-lo em favor das virtudes do seu protetor. Veremos mais adiante como o cronista utilizou a retórica judicial para tratar deste assunto.

O capítulo V ("No qual fala sumariamente das cousas notaveis que o Infante D. Henrique fez por serviço de Deus e honra do Reino") prossegue demonstrando como o ânimo virtuoso do príncipe ocupou-se das circunstâncias externas. E, como que para ofuscar a derrota na batalha de Tânger, o autor principia falando da conquista de Ceuta, "chave de todo o mar Medioterreno". ${ }^{73}$ Para tanto faz uso da hipotipose, figura de argumento "que consiste em pintar o objeto de que se fala de maneira tão viva que o auditório tem a impressão de tê-lo diante dos olhos". ${ }^{74}$ E eis o "valente cavalleiro" D. Henrique empenhado 
pessoalmente no embate, o primeiro capitão real a filhar as terras próximas ao muro da cidade e a adentrá-la com sua bandeira. Lá, isolado com mais quatro, combate uma "grande multidom de inimigos" que encontram no fio da espada do Infante a morte. Sua coragem é então recompensada com sua sagração como cavaleiro ainda em Ceuta e, depois, como duque no Algarve. ${ }^{75}$

A influência das novelas de cavalaria é explícita neste trecho. E não apenas na dedicatória, mas em todo o relato subsequente dos feitos no Marrocos e na Guiné. Segundo José de Bragança, "o mais comezinho e trivial assalto à mão armada contra Mouros, Azenagues ou Negros é narrado em estilo mavórtico, empregando até as expressões 'poer praça' e 'vencimento', como se se tratasse de algum cerco em regra ou de gloriosas batalhas". ${ }^{76}$ Zurara decididamente não foi parcimonioso no uso de amplificações.

$\mathrm{O}$ capítulo $\mathrm{V}$ continua relatando outras coisas dignas de nota obradas pelo Infante D. Henrique: povoamento e exploração de ilhas do "Mar Oceano", grandes doações à Igreja e a fundação de uma vila no Cabo de São Vicente, chamada Vila do Infante. Dizendo-se constrangido por ter de interromper a relação das grandes obras virtuosas do príncipe, Zurara diz que muitas outras há, e que poderão ser contempladas pelo leitor na Crônica Geral do Reino. ${ }^{77}$

A conclusão do elogio, segundo a Retórica a Herênio, deve ser breve e, preferencialmente, trazer uma enumeração. ${ }^{78}$ Zurara arremata a dedicatória evidenciando os fins, ou os objetivos, por trás dos grandes feitos de D. Henrique. É por isto que, no sétimo capítulo, último da dedicatória da crônica ao príncipe, são enumeradas "cinco razões por que o Senhor Infante foi movido de mandar buscar as terras de Guiné". São elas: 1': conhecer as terras além do Cabo Bojador; $2^{\mathrm{a}}$ : fazer comércio com povos cristãos que porventura habitassem aquelas paragens; $3^{\mathrm{a}}$ : saber até onde ia o poderio dos mouros na costa ocidental africana; $4^{\text {a }}$ : encontrar reis cristãos e a eles se aliar na luta contra os mouros; $5^{\text {a: }}$ converter os gentios e salvar suas almas. ${ }^{79}$

Inesperadamente, porém, Zurara aponta uma sexta razão para a busca das terras da Guiné, e que é, segundo ele, raiz de todas as outras: a "inclinação das rodas celestes", ou seja, a influência dos astros. Vale ressaltar que a enumeração de que trata a Retórica a Herênio consiste em trazer à memória dos leitores os argumentos que já foram apresentados para concluir o discurso. ${ }^{80} \mathrm{~A}$ princípio é o que Zurara faz. Mas quando anuncia cinco razões já desenvolvidas e irrompe com uma sexta, sem prévio aviso, o cronista busca provocar em seus leitores o efeito de surpresa. Ademais, ao subverter uma ordem que ele mesmo estabelecera na didascália do capítulo, Zurara obliquamente transmite a idéia de que as virtudes do príncipe não são enumeráveis, mas sim inumeráveis.

Uma vez concluída a análise do uso de preceitos da retórica epidítica na dedicatória da Crônica da Guiné, retornemos agora ao sexto capítulo, onde 
Zurara defende seu príncipe protetor da acusação de ter 'falecido na justiça distributiva', conforme anunciamos mais acima. Vejamos como ele faz isso valendo-se, desta feita, da retórica judicial.

\section{A DEDICATÓRIA DA CRÔNICA DA GUINÉ E A RETÓRICA JUDICIAL}

Os principais encargos do rei português nos Quatrocentos eram basicamente "a defensão do reino, a administração e a justiça" ${ }^{81} \mathrm{Ou}$, segundo nos diz Hespanha, a aplicação da justiça talvez fosse mesmo o único fim do poder político detido pelo rei, garantindo assim a harmonia entre os membros do corpo social. ${ }^{82}$ Enquanto defensores dos domínios reais, os primeiros reis portugueses, sendo cristãos, tiveram de levar adiante a luta contra os mouros infiéis. Luta esta que ultrapassou a Península Ibérica e aportou em terras africanas com a conquista de Ceuta, em 1415. O fato é que, para além dos interesses de chegar ao Oriente através do périplo africano - e a própria Guiné era considerada pelo cronista vizinha do Egito e das Índias ${ }^{83}-$, os portugueses buscavam imediatamente o acesso ao ouro transaariano, do qual Ceuta era um dos portos de exportação. Ademais, as guerras contra os muçulmanos marroquinos serviam também para justificar o espírito cavalheiresco de cristãos velhos e aprovisionar o reino dos primeiros escravos africanos. ${ }^{84} \mathrm{O}$ norte da África não era, pois, de forma alguma desprezível.

Tal espírito de cavalaria e cruzadístico foi personificado pelo Infante D. Henrique, porta-voz da nobreza guerreira e sedenta de terras por conquistar. Ele vinha tentando convencer seu irmão, o rei D. Duarte, a levar adiante tal empreendimento, desta feita contra outra cidade portuária marroquina, Tânger. ${ }^{85}$ Tudo a contragosto de seu outro irmão, o Infante D. Pedro, que via a expansão militar sobre o Marrocos com maus olhos. Para ele a aventura ultramarina com objetivos comerciais aparentava ser bem mais proveitosa ${ }^{86} \mathrm{D}$. Pedro, representante da burguesia, considerava mesmo a Ceuta já conquistada um "sumidoiro de homens", conforme carta enviada a seu irmão, o rei D. Duarte, em $1426 .{ }^{87}$ Explorar as ilhas e a costa africana pacificamente com fins unicamente comerciais era o que D. Pedro aconselhava D. Duarte a fazer. Investir contra Tânger seria um despropósito.

Antes de decidir-se o rei ouviu seus outros irmãos. O caçula, o Infante D. Fernando, pensava como D. Henrique, e, desejoso de glória cavalheiresca, optou pelo partido da guerra. D. Fernando, que pensava voltar sagrado cavaleiro do Marrocos, lá morreria como "Infante Santo" na memória coletiva portuguesa. ${ }^{88}$ Outro irmão do rei, o Infante D. João, como que para contrabalançar, arrazoou que enquanto o siso diz que não se deve deixar o certo pelo duvidoso, a cavalaria 
ignora tal regra. Ademais, matar mouros com más intenções, segundo o Infante D. João, era pecado, e melhor seria convertê-los por pregação. ${ }^{89}$ Entre os irmãos legítimos, portanto, deu empate: D. Pedro e D. João, por um lado, contra uma expedição para tomar Tânger, e D. Henrique e D. Fernando, por outro, a favor.

É o cronista Rui de Pina quem nos conta como se deu o embate dos partidos de D. Henrique e D. Pedro para obter o favor do indeciso rei, nos capítulos X a XX da sua Crônica d'El-Rei D. Duarte. ${ }^{90}$ Ali ficamos sabendo que, para neutralizar D. Pedro, D. Henrique manipulou a esposa do rei, D. Leonor. Isto parece ter sido decisivo, pois mesmo sem ouvir o Conselho D. Duarte acabou aprovando a expedição militar contra Tânger. "O consentimento foi naturalmente arrancado em alguma hora de ternura doce", segundo crê Oliveira Martins. ${ }^{91}$

Deveria o próprio rei D. Duarte, enquanto defensor da pátria e à semelhança dos monarcas que o antecederam, chefiar diretamente a expedição militar. Mas os reis predecessores de D. Duarte lutaram basicamente contra os mouros que haviam invadido a Península Ibérica e contra o perigo de Castela, reino vizinho que constantemente ameaçava invadir Portugal. Agora o contexto era outro. Com as primeiras conquistas no além-mar os monarcas portugueses passaram a evitar sair do país à frente do exército para que seu governo não fosse temporariamente interrompido, poupando assim o reino da necessidade de se estabelecerem regências durante a ausência real. ${ }^{92}$ Deste modo é que, no caso específico da campanha contra Tânger, o rei D. Duarte "redigiu instruções onde confessa que D. Henrique vai em seu lugar". ${ }^{93}$ Assim, investido da faculdade de comandar o exército português pelo próprio rei D. Duarte, o Infante D. Henrique, enquanto delegado real, detinha ali, no campo de batalha, as prerrogativas do rei citadas acima: defesa da pátria, administração e aplicação da justiça.

E quais foram as instruções dadas pelo rei ao seu obstinado irmão? Encontramo-las no "Conselho especial dado ao Infante D. Henrique quando se partiu para Tânger”, escrito pelo próprio D. Duarte e transcrito por José de Bragança. Das dez recomendações, destacamos a nona:

Que ponhaes bom provimento no que tiverdes sabendo como se faz, como pertence de o saber hum tal snr., fazendo bem aos bons servidores, e aos maus trabucadores e metideiros nom passem sem pena, que esta é a principal guarda que aos senhores pertence, que eles não podem ver tudo e convem que muitos leixem a lealdade por discreção de seus servidores, os quais por louvor e mercê dos bons, e escarmento dos maus, com a graça de Deus, se fazem bons e liaes. ${ }^{94}$ 
D. Duarte é categórico nesta passagem: os bons servidores na campanha de Tânger deveriam ser recompensados, mas os "maus trabucadores", ou seja, os maus trabalhadores, deveriam ser penalizados. Aplicação da justiça, pois, é o que o rei esperava de um senhor como o Infante D. Henrique: dar a cada um segundo o seu merecimento.

O resultado da batalha contra Tânger é conhecido: derrota humilhante dos lusitanos e captura do Infante D. Fernando, que caiu refém dos mouros e cujo valor de resgate correspondia à entrega de Ceuta, coisa que o próprio D. Henrique demoveu o rei de aceitar. O Infante D. Fernando acabou morrendo nas mãos dos marroquinos, em Fez, e a responsabilidade pode, portanto, ser imputada ao seu próprio irmão, o Infante D. Henrique..$^{95}$

Há, entretanto, outra falta cometida, e é esta que nos interessa especialmente: D. Henrique foi acusado de ter falhado na justiça distributiva, pois recompensara mais aos soldados que fugiram ao perceberem a derrota iminente do que aos combatentes que resistiram até o último momento. Assim, o Infante teria flagrantemente desconsiderado o conselho de seu irmão, o rei D. Duarte, a quem representava naquela ocasião: recompensar a cada um segundo o trabalho demonstrado no campo de batalha.

Tal acusação é reproduzida por Zurara na dedicatória da Crônica da Guiné, em seu sexto capítulo. Conforme vimos acima, a dedicatória da crônica segue os preceitos da retórica epidítica, já que se ocupa do louvor do Infante D. Henrique e de suas virtudes. Mas por que Zurara, num discurso laudatório, registra a funesta batalha de Tânger? E mais: por que reproduz a acusação de que o príncipe falhara na justiça distributiva? Ora, está claro que o cronista traz à baila os ditos atos censuráveis do Infante para refutá-los, para assim demonstrar, de um lado, sua perícia retórica, e, de outro, produzir um retrato irreprochável de D. Henrique. Portanto, Zurara precisou lançar mão não apenas da retórica epidítica para louvar o príncipe. Foi necessário também utilizar algumas tópicas da retórica judicial para defendê-lo na dedicatória da Crônica da Guiné.

Passemos, pois, a tratar da retórica judicial. No Livro III de sua Retórica, Aristóteles discorre sobre as tópicas de refutação. Segundo ele tais lugares podem ser utilizados nos três gêneros do discurso (deliberativo, judicial e epidítico). A refutação é para o Estagirita um dos componentes das provas, que, ao lado da exposição, são as duas partes realmente necessárias do discurso. ${ }^{96}$

Ora, tanto o acusador quanto o defensor podem utilizar tópicas de refutação. Mas há algumas delas que são próprias do defensor, segundo Aristóteles. Pode-se, por exemplo, "considerar que ou o facto não existe, ou que não é prejudicial; ou então que não o é para este indivíduo, ou não é tão importante; ou não é injusto ou não é muito; ou não é vergonhoso, ou não possui tal ordem de grandeza". ${ }^{97}$ Outra tópica de refutação específica do defensor 
consiste em ressaltar a beleza do ato dito injusto, ainda que este tenha trazido prejuízo a outrem. ${ }^{98}$

O autor da Retórica a Herênio divide o discurso em seis partes: exórdio, narração, divisão, confirmação, refutação e conclusão. Em todas elas o orador (ou autor) deve demonstrar sua invenção, que "é a descoberta de coisas verdadeiras ou verossímeis que tornem a causa provável". ${ }^{99} \mathrm{O}$ uso da invenção na confirmação e na refutação é tão importante para o orador latino que ele chega a dedicar aproximadamente metade do I Livro e quase todo o II Livro de sua obra para tratar exclusivamente deste tema. ${ }^{100}$ Vejamos então o que se diz sobre o uso da invenção na refutação.

Em primeiro lugar devemos destacar que, na Retórica a Herênio, as tópicas de refutação são utilizados essencialmente no gênero judicial. E a definição que ali encontramos de refutação é clara: "Refutação é a destruição dos argumentos contrários". ${ }^{101}$ É na confirmação e na refutação que estão "toda a esperança de vencer e todo o método de persuadir". ${ }^{102}$ Para que se confirme ou refute algo, porém, é necessário antes conhecer a constituição da causa, que pode ser de três tipos: conjectural, quando não há consenso a respeito de se o fato realmente ocorreu; legal, quando há controvérsia a respeito do texto da lei que versa sobre o suposto crime; e jurídica, "quando há acordo sobre o fato, mas pergunta-se se ele foi feito justa ou injustamente". ${ }^{103}$

Ora, como Zurara nem nega que o príncipe D. Henrique tenha realmente recompensado mais aos desertores do que aos soldados fiéis, nem questiona o texto da lei, inferimos daí que a constituição da causa em questão é jurídica. Tal tipo de constituição da causa se divide em duas partes: jurídica absoluta, quando se refuta dizendo que o ato foi praticado com justiça; e relativa, "quando a defesa é por si fraca e necessita de auxílio externo para comprovação". ${ }^{104} \mathrm{O}$ principal argumento do cronista será dizer que o que foi feito não foi injusto. Daí temos que a constituição da causa é jurídica absoluta.

Após identificar a constituição da causa, é hora de achar o motivo da defesa para o suposto erro. À acusação caberá apontar o fundamento, que se opõe ao motivo da defesa. Só então se terá a questão em julgamento, ou judicação. Como a Crônica da Guiné foi escrita pelo defensor do Infante D. Henrique, naturalmente encontraremos em tal documento o motivo que o autor expõe para eximir o príncipe de toda culpa. $\mathrm{O}$ fundamento da acusação já foi reproduzido pelo próprio Zurara: homens "entendidos" de seu tempo acusavam o príncipe de ter falhado na justiça distributiva. A questão em julgamento, portanto, é: quando o Infante D. Henrique recompensou mais aos trânsfugas do que aos soldados leais, teria ele realmente falhado na justiça distributiva?

Mas, afinal, qual o conceito de justiça no século XV lusitano? Aquele empregado por Aristóteles em sua Ética a Nicômaco, obra citada por Zurara e muito difundida na corte de Avis, a ponto de o próprio Infante D. Pedro tê-la 
traduzido para o português. O Livro V da Ética a Nicômaco trata exclusivamente da justiça, que, para Aristóteles, é a "virtude completa", já que encerra em si todas as outras virtudes: "É completa porque aquele que a possui pode exercer sua virtude não só sobre si mesmo, mas também sobre o seu próximo, já que muitos homens são capazes de exercer virtude em seus assuntos privados, porém não em suas relações com os outros". ${ }^{105}$

Há, conforme o filósofo, dois tipos de justiça: a distributiva e a corretiva. Enquanto esta se preocupa em corrigir as transações entre os indivíduos, a justiça distributiva "é a que se manifesta nas distribuições de honras, de dinheiro ou das outras coisas que são divididas entre aqueles que têm parte na constituição (pois aí é possível receber um quinhão igual ou desigual ao de um outro)". ${ }^{106}$

Falhar na justiça distributiva seria, pois, distribuir desigualmente, ou concedendo menos a quem era digno de mais, ou, pelo contrário, conferindo mais a quem não merecia tanto. Em outras palavras, 'falecer na justiça distributiva' corresponderia a recompensar sem atentar para os méritos dos indivíduos contemplados. Sabemos que para o Estagirita os homens não são naturalmente iguais, pois, conforme ele escreve em sua Poética, existem os que são "melhores, piores ou iguais a nós". ${ }^{107}$ Assim, ao se distribuir a justiça entre os homens deve-se observar a proporção, para que aquele que deve receber mais não seja lesado.

Ora, se a justiça é "virtude completa", a injustiça só pode ser "vício completo". Quem é injusto não consegue, portanto, manifestar nenhuma virtude. Assim, se o Infante D. Henrique falhou mesmo na justiça distributiva, isto por si só desmentiria todo o discurso laudatório feito por Zurara para o príncipe. Ou o cronista refuta o fundamento da acusação ou toda a sua retórica epidítica de enaltecimento do Infante cai por terra. Esse é o momento de a retórica judicial acudir à epidítica.

Lembremos que não se trata aqui necessariamente de um julgamento, mas de uma dedicatória do cronista para seu príncipe protetor. Assim, insistimos, por que reproduzir o fundamento da acusação contra D. Henrique? Não seria mais fácil desconsiderá-lo? Conforme vimos acima, tal acontecimento era recente e ficou marcado negativamente na memória do povo português, que passou a desacreditar os novos esforços propostos por D. Henrique a partir de então, segundo nos conta Zurara no capítulo XVIII de sua Crônica da Guiné:

E por semelhante fizeram no começo desta conquista que logo nos primeiros anos, vendo as grandes armações que o Infante fazia, com tamanhas despesas, leixavam o cuidado de suas próprias fazendas e ocupavam-se em departir o que pouco conheciam; e quanto a cousa tardava mais de vir a 
fim, tanto suas repreensões eram maiores. E o que peor era, que alem dos vulgares do povo, os outros maiores falavam em isso quasi por maneira de escarnho, tendo que eram despesas e trabalhos de que não podia vir algum proveito. ${ }^{108}$

Não eram apenas murmúrios de corte o que havia contra D. Henrique. $\mathrm{O}$ vexame de Tânger, que tanto depenara o reino em recursos e em vidas, gerou escárnio contra o Infante, desde os vulgos até os maiores. A estes últimos em especial - porque público-alvo direto do discurso de Zurara - convinha evidenciar o fundamento da acusação e refutá-lo.

Enfim, o que Zurara tem a dizer a seu público leitor e ouvinte sobre o malogro de Tânger? Eis as palavras do cronista para descrever o que sabemos ter sido uma derrota:

E depois, reinando el-Rei D. Duarte, por seu mando passou a terceira vez em Africa, na qual cercou a cidade de Tanger, indo XIX leguas com suas bandeiras tendidas por terra de seus inimigos, tendo-lhe o cerco XXII dias, nos quaes se fizeram mui assinaladas cousas, dignas de grande memoria, não sem grande dano dos contrarios, como na Historia do Reino melhor podeis saber. ${ }^{109}$

Somos tentados a fazer eco às palavras de José de Bragança: "se não conhecêssemos o desastroso sucesso, ele pareceria mais uma vitória do Infante". ${ }^{110}$ A derrota vexatória dos portugueses é subestimada, minimizada. Veja-se que o cronista amplifica as "mui assinaladas cousas" feitas pelo exército lusitano liderado por D. Henrique sobre a cidade moura. Zurara faz uso de amplificações também quando descreve exageradamente o "grande dano dos contrarios", ou seja, um suposto e superlativo prejuízo militar e material dos inimigos. De todos os eventos envolvidos na Batalha de Tânger apenas isto é digno de "grande memória", segundo Zurara. A derrota portuguesa aparece como um detalhe. Encontramos aqui as tópicas de refutação aristotélicas citadas atrás: o feito não é vergonhoso, nem possui a ordem de grandeza que os detratores atribuem a ele. Transformar o censurável em louvável: eis o efeito que a retórica judicial utilizada por Zurara busca provocar nos leitores, em confirmação de todo o louvor construído pela retórica epidítica.

Falemos agora especificamente da refutação com respeito ao falecimento na justiça distributiva. No capítulo VI ("No qual o autor, que ordenou esta historia, fala algumas cousas da sua intenção acerca das virtudes do Infante D. Henrique"), observamos ainda largo uso de amplificações. O cronista mais uma vez enaltece o Infante antes de defendê-lo propriamente - ou, se quisermos, defende-o pelo enaltecimento. Nenhum nobre ou príncipe, segundo Zurara, 
nascido antes do Infante ou seu contemporâneo, jamais excedera as virtudes de D. Henrique, que é mais honrado que os nobres da Antiguidade Romana louvados por Valério Máximo, e mais religioso, católico, prudente, avisado, temperado, magnânimo, franco, humano e forte que todos os príncipes europeus de seu tempo. ${ }^{111}$

Já no quarto capítulo Zurara afirmava seguir o conselho de Cícero: razoar sobre o que escreve, e com grande autoridade, já que é ele, o cronistamor, quem ordena a história, e o único que tem real compromisso para com a verdade dos acontecimentos - ou pelo menos com a verdade oficial. Diante de seu prestígio e sua autoridade as opiniões dos "outros homens" contaria muito pouco. É provável que aqui, ao trazer à tona suas atribuições como cronista-mor do reino, ou seja, guardião da memória institucionalizada da Dinastia de Avis, Zurara esteja se dirigindo obliquamente aos homens "entendidos" que haviam censurado D. Henrique. Eles não estariam capacitados a contar a história do Reino e de seus grandes homens a não ser de forma "desvairada".

Não, o príncipe avisino não falhou na justiça distributiva, segundo o cronista. Seu ato de recompensar mais aos desertores deve ser visto como manifestação da clemência e da humanidade do Infante para com os faltosos, qualidades essas mais desejáveis do que a correção militar que os entendidos esperavam que fosse aplicada. D. Henrique deve, portanto, ser louvado, e não censurado! E mais: o Infante deve ser glorificado ainda pela sua liberalidade em oferecer benefícios mesmo a quem os não merecia. Assim, se a justiça é a "virtude completa" porque permite a manifestação das demais virtudes para com o outro, o príncipe foi justo ao ser clemente e liberal para com os trânsfugas. Ao ressaltar, portanto, a beleza da ação dita injusta do Infante, Zurara usa da refutação sugerida por Aristóteles, como vimos acima. Deste modo, Zurara admite que o fato ocorreu, mas refuta a injustiça que lhe haviam imputado, conforme é próprio da constituição da causa jurídica absoluta definida na Retórica a Herênio, citada mais atrás.

Para pôr um ponto final a este suposto ato censurável do príncipe, Zurara sai-se com esta: "E como quer que seja, Principe mui excelente, estas cousas não sejam a ti graves, que não foi tanto minha intenção louvar os teus feitos, como a ti, porque muitas cousas dignas de louvor fazem os maus, mas não deve ser louvado senão o que em si for muito bom". ${ }^{112}$ As obras de D. Henrique são louváveis porque manifestam seu ânimo cheio de virtudes. Os maus, porém, também podem eventualmente fazer boas coisas, mas nem por isto são considerados virtuosos e dignos de louvor. D. Henrique, porque príncipe e nobre, está na categoria aristotélica "melhores do que nós". Mesmo que ele não tivesse praticado boas obras - o que não é o caso, segundo o cronista -, ainda assim, de acordo com a preceptiva aristotélica, seria possível elogiá-lo "se estivéssemos convencidos de que era capaz de as fazer". ${ }^{113}$ 
As exaustivas exposições dos feitos notáveis do príncipe elaboradas por Zurara agem no sentido de convencer os leitores de que o virtuoso Infante é sempre capaz de fazer boas obras, e isto basta. Assim, D. Henrique sequer precisava fazer o que fez em Tânger. Mas fez, e esse ato para com o outro foi, ao contrário do que se dizia, justo. O que significa dizer que D. Henrique era possuidor da "virtude completa", a justiça, inclusive a distributiva. Digno, portanto, de todo o louvor!

\section{CONSIDERAÇÕES FINAIS}

Diante do exposto, parece-nos claro que o panegírico elaborado por Gomes Eanes de Zurara para o Infante D. Henrique na sua Crônica da Guiné, enquanto discurso retoricamente regrado, fez uso do gênero epidítico, ou demonstrativo, na sua tentativa de construir uma persona verossímil do elogiado. E quando se fez necessário o cronista valeu-se também da retórica judicial para impedir que tanto o príncipe quanto a sua dedicatória fossem desacreditados. E isso estava muito de acordo com a atitude dos cronistas medievais que, conforme vimos com Guenée, privilegiavam a verossimilhança em detrimento da verdade.

Impossível não trazermos à baila o exemplo dado pelo Estagirita em sua Poética sobre a imitação dos poetas trágicos: "Se a tragédia é imitação de homens melhores que nós, importa seguir o exemplo dos bons retratistas, os quais, ao reproduzir a forma peculiar dos modelos, respeitando embora a semelhança, os embelezam!" 114 Assim o fez Zurara em seu discurso laudatório: pintou o retrato de um nobre da realeza com os preceitos do gênero epidítico. Tornou o príncipe mais belo do que de fato era, mas sem abrir mão da verossimilhança adequada a alguém 'melhor do que nós'.

\section{NOTAS}

1 ARISTÓTELES. Retórica. Tradução e notas de Manuel Alexandre Jr., Paulo Farnhouse Alberto e Abel do Nascimento Pena. Lisboa: Imprensa Nacional - Casa da Moeda, 1998, Livro I, parágrafo 2 .

2 CURTIUS, Ernst. Literatura europeia e Idade Média latina. Trad. Teodoro Cabral. Rio de Janeiro: Ministério da Educação e Cultura / Instituto Nacional do Livro, 1957, p. 230.

3 ARISTÓTELES, op. cit., Livro I, parágrafo 3.

4 Idem. Poética. Tradução, comentários e índices analítico e onomástico de Eudoro de Souza. São Paulo: Abril Cultural, 1973. (Coleção "Os Pensadores”, volume IV), Livro IX, parágrafo 50 . 
5 [CÍCERO]. Retórica a Herênio. Tradução e Introdução de Ana Paula Celestino Faria e Adriana Seabra. São Paulo: Hedra, 2005, Livro I, parágrafo 12.

6 CÍCERO apud AMBROSIO, Renato. De rationibus exordiendi: função e elaboração dos exórdios de Cornélio Nepos e Salústio Crispo. São Paulo: Associação Editorial Humanitas/ Fapesp, 2005, p. 38.

7 CÍCERO apud MALEVAL, Maria do Amparo Tavares. Fernão Lopes e a retórica medieval. Niterói: Editora da Universidade Federal Fluminense, 2010, p. 94.

8 ARISTÓTELES. Poética, Livro II, parágrafo 7.

9 GUENÉE, Bernard. História. In: LE GOFF, Jacques; SCHMITT, Jean-Claude. Dicionário temático do Ocidente Medieval. Coord. da tradução Hilário Franco Jr. Bauru, SP: EDUSC; São Paulo, SP: Imprensa Oficial do Estado, 2002. Volume I, p. 530.

${ }^{10}$ Ibid., p. 531.

11 BOURDÉ, Guy; MARTIN, Hervé. As escolas históricas. Portugal: Europa-América, 1983, p. 33.

${ }_{12}$ RICOEUR, Paul. A memória, a história, o esquecimento. Trad. Alain François et alii. Campinas, SP: Editora da UNICAMP, 2007, p. 98.

${ }_{13}$ MALEVAL, Maria do Amparo Tavares. Fernão Lopes e a retórica medieval. Niterói: Editora da Universidade Federal Fluminense, 2010, p. 75.

${ }^{14}$ CURTIUS, op. cit., p. 200.

15 SANTOS, João Marinho dos. A expansão pela espada e pela cruz. In: NOVAES, Adauto (org.). A descoberta do homem e do mundo. São Paulo: Companhia das Letras, 1998. p. 145162.

${ }^{16}$ CURTIUS, op. cit., p. 68.

17 HANSEN, João Adolfo. Categorias epidíticas da ekphrasis. Revista Usp. São Paulo, n. 71, p. $85-105$, set./nov. 2006, p. 87.

${ }^{18}$ CURTIUS, op. cit., p. 82.

19 HANSEN, op. cit., p. 86.

20 SOUSA, Armindo de. 1325-1480. In: MATTOS, José. (dir). História de Portugal. Segundo volume: A Monarquia Feudal (1096-1480). Lisboa: Editorial Estampa, 1997, p. 449.

${ }^{21}$ FERNANDES, R. M. Rosado. Breve introdução aos estudos retóricos em Portugal. In: LAUSBERG, Heinrich. Elementos de retórica literária. Tradução, prefácio e aditamentos de R. M. Rosado Fernandes. $4^{\mathrm{a}}$ ed. Lisboa: Fundação Lacouste Gulbenkian, 1972, p. 18.

${ }^{22}$ Idem. Retórica. In: IN: LANCIANI, Giulian; TAVANI, Giusepe (org. e coord.) Dicionário de literatura medieval galega e portuguesa. Tradução de José Colaço Barreiros e Arthur Guerra. Lisboa: Ed. Caminho S.A., 1993, p. 575.

${ }^{23}$ D. AFONSO V. Carta del Rei dom Affonso a Guomez Eanez da Zurara seu coronista, escrita per sua mão. In: ZURARA, Gomes Eanes de. Crónica da Tomada de Ceuta por El-Rei D. João I. Coimbra: Imprensa da Universidade, 1915, p. 305.

${ }^{24}$ FRANÇA, Susani Silveira Lemos. Os reinos dos cronistas medievais (século XV). São Paulo: Annablume; Brasília: Capes, 2006, p. 99. 
25 KRUS, L. Crônica de Portugal de 1419. In: LANCIANI, Giulian; TAVANI, Giusepe (org. e coord.) Dicionário de literatura medieval galega e portuguesa. Tradução de José Colaço Barreiros e Arthur Guerra. Lisboa: Ed. Caminho S.A., 1993, p. 186.

26 D. DUARTE apud FRANÇA, op. cit., p. 100.

27 D. AFONSO V, op. cit., p. 305-306.

${ }^{28}$ GUENÉE, op. cit., p. 526.

29 Ibid., loc. cit., grifo do autor.

30 Ibid., p. 525.

31 Ibid., p. 526-527.

32 KOSELLECK, Reinhart. Futuro passado: contribuição à semântica dos tempos históricos. Trad. Wilma Patrícia Maas, Carlos Almeida Pereira; revisão da tradução César Benjamin. Rio de Janeiro: Contraponto: Ed. PUC-Rio, 2006, p. 43-45.

33 BRAGANÇA, José de. Introdução. In: ZURARA, Gomes Eanes de. Crônica de Guiné. Segundo os ms. de Paris. Modernizada. Introdução, notas, novas considerações e glossário de José de Bragança. Barcelos: Livraria Civilização, 1973, p. XXXIX.

${ }^{34}$ LE GOFF, Jacques. História e memória. Tradução de Bernardo Leitão... [et al]. $4^{\mathrm{a}}$ ed. Campinas, SP: Editora da UNICAMP, 1996, p. 421-422.

35 GOMES, R. Costa. Zurara. In: LANCIANI, Giulian; TAVANI, Giusepe (org. e coord.) Dicionário de literatura medieval galega e portuguesa. Tradução de José Colaço Barreiros e Arthur Guerra. Lisboa: Ed. Caminho S.A., 1993, p. 687.

36 FRANÇA, Susani Silveira Lemos, op. cit., p. 136.

37 BOURDÉ; MARTIN, op. cit, p. 35.

38 BRAGANÇA, op. cit., XLI.

39 Tentativa fracassada dos portugueses, liderados pelo Infante D. Henrique, de tomar a cidade moura de Tânger, no norte africano, em 1437.

40 Batalha na qual se enfrentaram o rei D. Afonso V e seu tio, o Infante D. Pedro, o qual havia sido tutor e regente daquele durante sua menoridade. Intrigas de corte e interesses opostos da nobreza e da burguesia levaram a tal embate, que culminou na morte de D. Pedro e seus partidários, em 1449.

41 BOURDÉ; MARTIN, op. cit., p. 28.

42 O termo "Guiné” assume dois sentidos na Crônica da Guiné. Um geral, que designa todas as terras encontradas após o Cabo Bojador, incluídas aí a "terra dos Mouros Azenegues", também chamada de "Zaara", e a "terra dos Negros". Há casos, porém, em que a palavra "Guiné" deve ser entendida em algumas passagens da Crônica em seu sentido estrito, qual seja, "terra dos Negros, ou terra de Guiné, por cujo azo os homens e mulheres dela são chamados Guineus, que quer tanto dizer como negros", segundo nos informa o próprio ZURARA, op. cit., p. 256.

43 Segundo BRAGANÇA, op. cit, p. LXXIX-LXXXIV, a Crônica da Guiné apresentada em Roma fora feita às pressas para a obtenção da bula Romanus Pontifex, e muito se aproxima da versão encontrada no manuscrito de Valentim Fernandes. O códice achado pelo Visconde da Carreira na Biblioteca de Paris, em 1837, e impresso sob os cuidados do Visconde de Santarém, 
em 1841, seria uma versão ampliada e "melhorada" da mesma crônica. Nosso estudo tem por base o códice de Paris, que "não é a primeira redacção da Crónica, mas uma cópia nem sempre fiel de um original perdido, com interpolações várias, posteriores a 1453".

${ }^{44}$ ZURARA, op. cit., p. 13.

${ }^{45}$ Esta obra de autoria anônima, produzida no século I a.C., em Roma, figura entre os tratados de retórica mais utilizados na Península Ibérica no período medieval. Até o século XV, porém, a Retórica a Herênio era atribuída a Cícero e era compartilhada em códices juntamente com o Da Invenção, de autoria ciceroniana. Como as retóricas latinas partem da Retórica de Aristóteles e estabelecem uma relação de emulação com os gregos antigos, faremos também referências à obra do Estagirita, ainda que esta não tenha sido utilizada em Portugal na época de nosso estudo.

${ }^{46}$ [CÍCERO], op. cit., Livro III, parágrafos 10-11.

${ }^{47}$ Ibid., Livro III, parágrafo 15.

${ }^{48}$ Ibid., Livro III, parágrafo 11.

${ }^{49}$ ZURARA, op. cit., p. 09.

${ }^{50}$ REBOUL, Olivier. Introdução à retórica. Tradução de Ivone Castilho Benedetti. São Paulo: Martins Fontes, 2004, p. 246.

${ }^{51}$ ZURARA, op. cit., p. 14 e 16.

${ }^{52}$ Ibid., p. 17.

${ }^{53}$ Ibid., p. 18.

${ }^{54}$ [CÍCERO], op. cit., Livro III, parágrafo 13.

${ }^{55}$ Ibid., Livro I, parágrafo 14.

${ }^{56}$ ZURARA, op. cit., p. 22.

57 Ibid., p. 20.

${ }^{58}$ MARTINS, Oliveira. Os filhos de D. João I. Lisboa: Guimarães \& Cia. Editores, 1958. Tomo I, p. 75.

${ }_{59}$ [CÍCERO], op. cit., Livro III, parágrafo 14.

${ }^{60}$ ZURARA, op. cit., p. 21.

${ }^{61}$ Ibid., p. 22.

62 Ibid., p. 22-23.

${ }^{63}$ Ibid., p. 24.

${ }^{64}$ Ibid., loc. cit.

${ }^{65}$ Ibid., p. 25.

${ }^{66}$ REBOUL, op. cit., p. 46 e 50.

${ }^{67}$ MARTINS, op. cit., p. 72.

${ }^{68}$ BRAGANÇA, op. cit., p. XXXV.

${ }^{69}$ [CÍCERO], op. cit., Livro III, parágrafo 14. 
70 ZURARA, op. cit., p. 22.

71 Ibid., p. 23.

72 [CÍCERO], op. cit., Livro I, parágrafo 16.

73 ZURARA, op. cit., p. 27.

74 REBOUL, op. cit., p. 136.

75 ZURARA, op. cit., p. 27-29.

76 BRAGANÇA, op. cit., p. XXXVIII.

77 ZURARA, op. cit., p. 29-34.

78 [CÍCERO], op. cit., Livro III, parágrafo 15.

79 ZURARA, op. cit., p. 43-46.

80 [CÍCERO], op. cit., Livro II, parágrafo 47.

81 FRANÇA, Eduardo d'Oliveira. O poder real em Portugal. In: Boletim LXVIII - História da Civilização Antiga e Medieval. n. 06, Univ. de S. Paulo, Fac. Filosofia, Ciências e Letras, São Paulo, 1946, p. 165.

${ }^{82}$ HESPANHA, António Manuel. As vésperas do Leviathan: Instituições e poder político. Portugal - séc. XVII. Lisboa: Almedina, 1994.

83 ZURARA, op. cit., p. 86, 147.

84 SILVA, Alberto da Costa e. A manilha e o libambo: a África e a escravidão, de 1500 a 1700. Rio de Janeiro: Nova Fronteira: Fundação Biblioteca Nacional, 2002, p. 143 e 151.

85 Enquanto Ceuta era considerada a "chave do Mediterrâneo" por ser a cidade norte-africana mais ocidental banhada por este mar, Tânger, cidade próxima, localizava-se já na orla do Oceano Atlântico, então chamado de "Mar Oceano".

${ }^{86}$ MARQUES, A. H. de Oliveira. História de Portugal - Volume I: das origens ao Renascimento. Lisboa: Editorial Presença, 1997, p. 218.

87 D. PEDRO apud BRAGANÇA, op. cit., p. XLIV.

${ }^{88}$ MARTINS, op. cit., p. 242.

89 BRAGANÇA, op. cit., p. XLV-XLVI.

90 PINA, Rui de. Chronica d'El-Rei D. Duarte. Porto: Edição da Renascença Portuguesa, 1914.

91 MARTINS, op. cit., p. 245.

92 FRANÇA, Eduardo d'Oliveira, op. cit., p. 166-168.

93 Ibid., loc. cit.

94 D. DUARTE apud BRAGANÇA, op. cit., p. XXXVII.

95 MARQUES, op. cit., p. 237.

96 ARISTÓTELES, Retórica, Livro III, parágrafo 13.

97 Ibid., Livro III, parágrafo 15. 
98 Ibid., loc. cit.

99 [CÍCERO], op. cit., Livro I, parágrafo 3.

${ }^{100}$ A Retórica a Herênio é dividida em cinco partes, ou livros.

${ }^{101}$ [CÍCERO], op. cit., Livro I, parágrafo 4.

${ }^{102}$ Ibid., Livro I, parágrafo 18.

${ }^{103}$ Ibid., Livro I, parágrafos 18-24.

${ }^{104}$ Ibid., Livro I, parágrafo 24.

${ }^{105}$ ARISTÓTELES. Ética a Nicômaco. Tradução direta do grego por Vincenzo Cocco e notas de Joaquim de Carvalho. São Paulo: Abril Cultural, 1973. (Coleção "Os Pensadores", volume IV), Livro V, parágrafo 1.

${ }^{106}$ Ibid., Livro V, parágrafo 2.

${ }^{107}$ ARISTÓTELES, Poética, Livro II, parágrafo 7.

${ }^{108}$ ZURARA, op. cit., p. 96.

${ }^{109}$ Ibid., p. 19-30.

${ }^{110}$ BRAGANÇA, op. cit., p. XLI.

${ }^{111}$ ZURARA, op. cit., p. 37.

${ }^{112}$ Ibid., p. 42.

${ }^{113}$ ARISTÓTELES, Retórica, Livro I, parágrafo 10.

${ }^{114}$ Idem, Poética, Livro XV, parágrafo 90.

Artigo recebido em agosto de 2011. Aceito em abril de 2012. 